\title{
Relationships Between Retinal Break Locations And The Shapes Of The Detachments [Corrigendum]
}

Yoshida I, Shiba T, Hori Y, Maeno T. Clin Ophthalmol. 2018;12:2213-2222.

On page 2213, Yuichi Hori and Takatoshi Maeno's affiliations have been updated. The correct author list and affiliations should be as follows:

Izumi Yoshida ${ }^{1}$, Tomoaki Shiba ${ }^{2}$, Yuichi Hori ${ }^{2}$, Takatoshi Maeno ${ }^{1}$
${ }^{1}$ Department of Ophthalmology, Toho University Sakura Medical Center, Chiba, Sakura, Japan; ${ }^{2}$ Department of Ophthalmology, Toho University Omori Medical Center, Tokyo, Japan

\section{Publish your work in this journal}

Clinical Ophthalmology is an international, peer-reviewed journal covering all subspecialties within ophthalmology. Key topics include: Optometry; Visual science; Pharmacology and drug therapy in eye diseases; Basic Sciences; Primary and Secondary eye care; Patient Safety and Quality of Care Improvements. This journal is indexed on PubMed
Central and CAS, and is the official journal of The Society of Clinical Ophthalmology (SCO). The manuscript management system is completely online and includes a very quick and fair peer-review system, which is all easy to use. Visit http://www.dovepress.com/ testimonials.php to read real quotes from published authors. 